Supplement of Biogeosciences, 18, 1793-1801, 2021

https://doi.org/10.5194/bg-18-1793-2021-supplement

(C) Author(s) 2021. CC BY 4.0 License.

(c) (1)

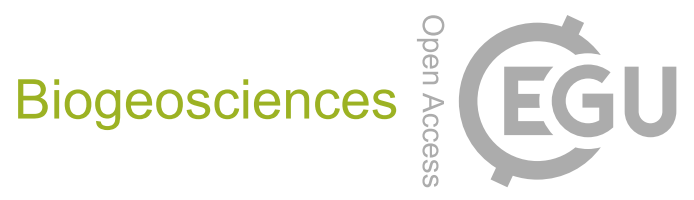

Supplement of

\title{
Characterizing the origins of dissolved organic carbon in coastal seawater using stable carbon isotope and light absorption characteristics
}

\author{
Heejun Han et al. \\ Correspondence to: Guebuem Kim (gkim@snu.ac.kr)
}

The copyright of individual parts of the supplement might differ from the article licence. 

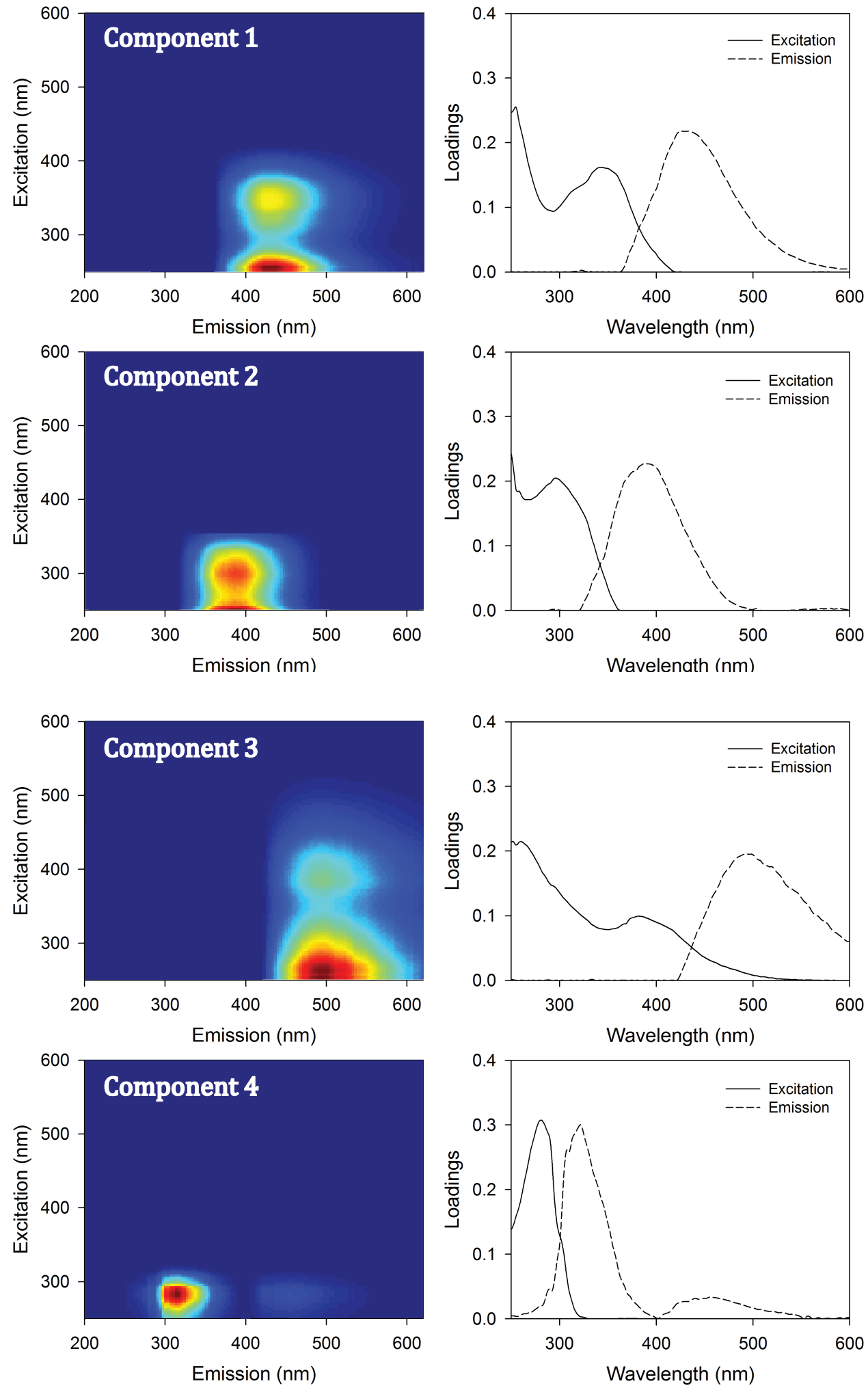

Figure S1. Contour plots of fluorescence EEM spectra and excitation-emission loadings of terrestrial humic-like $\left(\mathrm{FDOM}_{\mathrm{C}}\right.$ and $\left.\mathrm{FDOM}_{\mathrm{A}}\right)$, marine humic-like $\left(\mathrm{FDOM}_{\mathrm{M}}\right)$, and protein-like (tryptophan-like; FDOM $_{P}$ ) components identified using the PARAFAC model in Sihwa Lake. 